\title{
PREVALENCE OF ANTHROPOMETRIC AND CARDIOVASCULAR RISK FACTORS AMONG BULGARIAN UNIVERSITY STUDENTS
}

\author{
Silviya Mladenova \\ University of Plovdiv "Paisii Hilendarski", Branch Smolyan, Faculty of Biology, \\ "Todor Samohodov" Plovdiv, Bulgaria
}

Summary. The aim of this paper is to investigate the prevalence of cardiovascular risk factors and their conection with health risk anthropometrical factors among Bulgarian university students, the main in the South Bulgaria. The sample population of the study included total 386 young people, of which 303 females and 83 males, between 18-30 years of age i.e. the mean age is 21.3-21.4 years. They were from different regions of Bulgaria, mainly from Southern Bulgaria.The study was conducted transversally in the period between 2015 and 2017. For each person the weight, height, waist circumference and blood pressure were measured. On this base the body mass index and waist to height ratio were calculated by formulas. Underweight was defined as BMK $18.5 \mathrm{~kg} / \mathrm{m} 2$, overweight as BMl $25-29.9 \mathrm{~kg} / \mathrm{m} 2$ and obesity as $\mathrm{BMI} \geq 30 \mathrm{~kg} / \mathrm{m} 2$. Waist-to-height ratio $(\mathrm{WHtR})$ was used for evaluation of central (abdominal) obesity, that was defined as $\mathrm{WHtR} \geq 0.5$. The prehypertension was defined when SBP $>120<139$ and/or DBP $>80<89 \mathrm{mmHg}$ and hypertension when SBP $\geq 140$ and/or DBP $\geq 90 \mathrm{mmHg}$. The statistical processing of the data was done using software package Statistica 10.0 and SPSS 20.0 by means of descriptive statistics and multiple regression analysis. The results show that the underweight occurs among $1.2 \%$ of the men and among $15.2 \%$ of the women, the overweight occur among $32.5 \%$ of men and $13.9 \%$ of women and obesity was found among $10.8 \%$ of the men and $8.6 \%$ of the women.Central obesity occur among $32 \%$ of males and $17 \%$ of females, independently of their nutritional status. The prehypertension occur among $46 \%$ of the men and $28 \%$ of the women. The hypertension found among $18 \%$ of the men and among $2 \%$ of the women. Among male students with prehypertension the overweight occur among $35.7 \%$, and obesity occur among $10.7 \%$ of participants, while among hypertensive male the overweight and obesity occurs in $18.2 \%$ and $36.4 \%$, respectively. In group of prehypertensive females $22.4 \%$ are overweight and $14.9 \%$ are obese. Hypertension occur among $20 \%$ of overweight and $40 \%$ of obese female students. In group of central obese male the prehypertension and hypertension occurs among $55 \%$ and $20 \%$, respectively. Among central obese females $47.5 \%$ are prehypertensive and $7.5 \%$ are hypertensive. The results also show that the waist circumference has a serious potential to influence on the blood pressure level at an early adulthood in both sexes. The higher prevalence of elevated blood pressure, overweight, general and central obesity among Bulgarian university students maybe connect with factors such as a sex, hormonal status, hereditary burden and sexual differences in some lifestyle habits as a nutrition, smoking, alcohol consumption, physical activity, individual physiological and biochemical status, psychological stress during student life and other. The prevalence of this risk factors among young Bulgarian adults needs of urgent attention and further evaluation because of the grave consequences of obesity and hypertension and because the hypertension and overweight is an important amendable risk factors in young life.

Key words: Prehypertension. Hypertension. Overweight. Obesity. Central Obesity. Bulgarian university students.

Autor za korespondenciju: Silviya Mladenova, e-mail: silviamladenova.sm@gmail.com

University of Plovdiv "Paisii Hilendarski", Smolyan Branch, 32 "Dicho Petrov Str", 4700 Smolyan, Bulgaria

Primljeno u redakciju 29. 12. 2018, revidirana verzija 8. 3. 2018, rad prihvaćen za publikovanje 25. 3. 2019. 


\section{Introduction}

The cardiovascular disease was estimated to be the leading cause of death and disability in worldwide. Most of cardiovascular disease events nowadays are taking place in low and middle income countries with $80 \%$ of the burden occurring in these countries (Mackay, Mensah, 2004). The development of major cardiovascular risk factors at an early age is closely related to clustering of risk factors and health behaviour (Paavola et al., 2004). Hypertension, dyslipidemia, glucose intolerance and overweight are usually tolerated at a younger age (Rogacheva et al., 2006). Overtime these conditions especially if associated with overweight and obesity, poor dietary habits, smoking or physical inactivity can lead to higher risk of metabolic and cardiovascular disease and of excessive morbidity and mortality in late adulthood (Li et al., 2003; Andreenko, 2005; Andreenko, 2009).

The global burden of cardiovascular diseases (CVD) is increasing around the world, in Bulgaria as well. Among 15 European countries, Bulgaria ranked first among men and fifth among women with respect to the increase in cardiovascular disease mortality between 1970 and 2012, and now has among the highest rates of both coronary heart disease and stroke mortality in Europe.According to data from the World Health Organization $64 \%$ of mortality as a percent of total deaths in Bulgaria in 2012-2013 years are caused by cardiovascular diseases (World Health Organization, 2015). Because of this 'dark' statistics Bulgaria comes to one of the top places in the World. The report of the WHO highlights high blood pressure, overweight and obesity as major metabolic risk factors and everyday smoking and lack of exercise - as major behavioral risk factors. The report further reads that men in Bulgaria tend to be more vulnerable and suffer higher morbidity and mortality compared to women (World Health Organization,2015). The risks factor for CV diseases might differ among different countries and populations, which will affect the implementation of intervention programs.

In Bulgaria they were many investigation about risk factors for CVD and other disease in adults (Dyakova et al., 2008; Andreenko et al., 2015a; 2015b; Andreenko et al., 2017). A representative sample of Bulgarian urban population $(n=3810)$ from five Bulgarian cities was inlcuded in a cross-sectional observation study performed in the period 2005-2007 from Dyakova et al.(2008). The results of this study shows that the cardiovascular risk is high in a large proportion of Bulgarian urban population, especially in men aged over 65 years.

The many research reported for prevalence of anthropometric, cardiovascular and environmental risk factors in children, adolescents and young adults from various countries - in Bulgaria (Nikolova,1997; Nikolova et al., 2005; Andeenko and Nikolova, 2010; Mitova, 2010; Mladenova and Andreenko, 2015; Andreenko et al., 2015a, 2015b), Turkey (Aynaci, Akdemir, 2018), Serbia (Stojanovic, 2009; Crnobrnja et al., 2012), Portugal (Brandao et al., 2008),Columbia (Feliciano-Alfonso, 2010), Japan (Furukawa et al., 2009), Jordan (Gharaibeh et al., 2012), Egypt (Farrag et al., 2015), India (Jain et al., 2014, Malaysia (Cheah et al., 2018) and many other.

In connect to the fact that overweight and obesity were the significant risk factors for CVD the many autors reported for prevalence of overweight and obesity among Bulgarians-children, young and older (Petrova et al., 2012; Birdanova et al., 2013; Mitova, 2010; Mladenova and Andreenko, 2015; Andreenko et al., 2015a, 2015b). The rising percentage in recent years of overweight and obese people in Bulgaria who also suffer prehypertension and hypertension, including young people, as well as the high morbidity and mortality of adults because of cardiovascular diseases undoubtedly raise very serious concerns. This makes early diagnostics and prevention from these abnormalities especially important still in early adulthood. 


\section{Objective}

To study of prevalence of the cardiovascular risk factors among Bulgarian university students and their relationship with some anthropometric indicators.

\section{Methodology}

\section{Sample}

The subject of this study are 386 Bulgarian students in Plovdiv University "Paisii Hilendarski" range from 18 to 30 years (mean age 21.3years), of which 303 women $(78.5 \%)$ and 83 men (21.5\%). They were from different regions of Bulgaria, mainly from Southern Bulgaria. The study was conducted transversally in the period between 2015 and 2017.

In sample include only clinically healthy students with Bulgarian nationality and origin.

\section{Ethics}

The study was conducted with the official approval of the Ethical Committee on Plovdiv University - Branch Smolyan. The written informed consent of each person included in the research group was obtained, in accordance with the ethical principles for medical research involving human subjects in the Helsinki Declaration of World Medical Association (2000).

\section{Study design}

The study design included a four directly measured anthropometric and functional indicators: height $(\mathrm{H}, \mathrm{cm})$, weight $(\mathrm{W}, \mathrm{kg})$, waist circumference $(\mathrm{WC}, \mathrm{cm})$, systolic and diastolic blood pressure $(\mathrm{mmHg})$. On this base two additional indexes were calculated body mass index (BMI, $\mathrm{kg} / \mathrm{m}^{2}$ ), and waist to height ratio (WHTR).

\section{Methods}

The anthropometric data of height $(\mathrm{H}, \mathrm{cm})$, weight $(\mathrm{W}, \mathrm{kg})$ and waist circumference (WC,cm), of each person were measured using the Martin-Saller's anthropometrical method (1957), by means of original anthropometric instruments (GPM, Swiss). Furthermore, the Body Mass Index (BMI) and the Waist to Height Ratio (WHTR) were calculated. The Body Mass Index (BMI) was calculated by the formula: Weight $(\mathrm{kg}) /$ Height $\left(\mathrm{m}^{2}\right)$. The Waist-toHeight Ratio (WHTR) was calculated by the formula: Waist circumference $(\mathrm{cm}) /$ Height $(\mathrm{cm})$. The categories of anthropometric nutritional status was assessed through in accordance with recommendations of the International Obesity Task Force (IOTF) for BMI cut-off points of adults, where the values of $\mathrm{BMI}<18.5 \mathrm{~kg} / \mathrm{m}^{2}$ is underweight, values between $18.5-24.9 \mathrm{~kg} / \mathrm{m}^{2}$ is normal weight, values from $25-29.9 \mathrm{~kg} / \mathrm{m}^{2}$ is overweight, and BMI $\geq 30 \mathrm{~kg} / \mathrm{m}^{2}$ is obesity (WHO, 1995). The central obesity was assessed on the base on a relation between the waist circumference and height (WHTR), where WHTR $<0.500$ is without central obesity and WHTR $\geq 0.500$ is central obesity (Hsieh, Muto, 2005).

The blood pressure was measured twice using auscultation method of Korotkoff, phases I and V using a "SENDO"(Japan) mechanical sphygmomanometer and stethoscope. The two measurements of the blood pressure (BP) were taken within an interval of one minute. If the difference in the $\mathrm{BP}$ was more than $5 \mathrm{mmHg}$, one additional reading was taken, and 
the two readings closest in value (nearest to two decimal points) were used for data entry.The final reading used in analysis was based on the average of the two readings recorded.The evaluation of categories blood pressure was defined in three categories (normotension, prehypertension and hypertension), according to recommendations of the Seventh Report of the Joint National Committee on Prevention, Detection, Evaluation, and Treatment of High Blood Pressure - JNC 7 (Chobanian et al., 2003). The normotension was defined when SBP $<120$ and/or DBP $<80 \mathrm{mmHg}$, prehypertension was defined when SBP $>120<139$ and/or DBP $>80<89 \mathrm{mmHg}$. Hypertension was defined in value of $\mathrm{SBP} \geq 140$ and/or $\mathrm{DBP} \geq 90 \mathrm{mmHg}$.

The statistical processing of the data was done using software packages STATISTICA 10.0 and SPSS 20.0 by means of descriptive statistics and multiple regression analysis. The intergroup differences were assessed by usingT-test of Student and Chi-square test.

\section{Results}

The mean and SD of anthropometric and blood pressure variables of the studied population are shown in Table 1. As can be seen in table the average mean age of the studied individuals was 21.2 \pm 2.4 years, with a range of 19-30 year. Males were significantly taller, heavier, and had significantly higher mean values of waist circumference (WC), body mass index (BMI), waist to height ratio (WHtR), systolic blood pressure(SBP) and diastolic blood pressure (DBP). There were significant difference in mean of all anthropometric and physiological indicators between males and females $(\mathrm{p}<0.000)$.

Table 1. Basic characteristics of the studypopulation

\begin{tabular}{|c|c|c|c|}
\hline \multirow[t]{2}{*}{ Variables } & $\begin{array}{l}\text { Males } \\
(\mathrm{n}=83)\end{array}$ & $\begin{array}{c}\text { Females } \\
(\mathrm{n}=303)\end{array}$ & \multirow[t]{2}{*}{ p-level } \\
\hline & $($ mean $\pm S D)$ & $($ mean \pm SD $)$ & \\
\hline Age (year) & $21.3 \pm 2.4$ & $21.1 \pm 2.3$ & $>0.05$ \\
\hline Height $(\mathrm{cm})$ & $175.1 \pm 6.2$ & $162.9 \pm 6.3$ & $<0.000^{*}$ \\
\hline Weight (kg) & $76.6 \pm 16.2$ & $60.1 \pm 13.8$ & $<0.000^{*}$ \\
\hline Waist circumference $(\mathrm{cm})$ & $83.3 \pm 10.9$ & $71.8 \pm 9.8$ & $<0.000^{*}$ \\
\hline Body mass index $\left(\mathrm{kg} / \mathrm{m}^{2}\right)$ & $24.9 \pm 4.9$ & $22.6 \pm 4.9$ & $<0.000^{*}$ \\
\hline Waist to height ratio & $0.475 \pm 0.06$ & $0.441 \pm 0.06$ & $<0.000^{*}$ \\
\hline Systolic blood pressure $(\mathrm{mm} / \mathrm{Hg})$ & $119.9 \pm 13.8$ & $108.6 \pm 11.8$ & $<0.000^{*}$ \\
\hline Diastolic blood pressure $(\mathrm{mm} / \mathrm{Hg})$ & $75.8 \pm 11.6$ & $70.6 \pm 8.5$ & $<0.000^{*}$ \\
\hline
\end{tabular}

In Table 2 are present the results of the percentage distribution of the Bulgarian students being surveyed according to the different type of body nutritional status and blood pressure. The distribution of the individual ssurveyed according to the different categories of body nutritional status, based on BMI shows that the most common in both sexes is the normal body nutritional status in over half of those surveyed. Among women, second most common deviation is underweight $-15.2 \%$, while overweight and obesity occur among total of $22.5 \%$ $13.9 \%$ and $8.6 \%$, respectively. Among the young men surveyed, the most common deviation from the normal nutritional status is overweight, which occurs in $32.5 \%$, and obesity $-10.8 \%$. Underweight is rarely encountered, found among $1.2 \%$ of men. The differences in the percentage distribution of the persons surveyed by categories between both sexes are statistically significant ( $p<0.0000$ ). Central obesity (WHTR $\geq 0.5$ ), assessed on the basis of WHTR occurs in almost $31.7 \%$ of the men surveyed, compared with the female, where it is 
found in about $17 \%$ of those surveyed. The gender differences are statistically significant $(\mathrm{p}<0.002)$. The percentage distribution of different blood pressure categories based on the limit values of systolic blood and diastolic blood pressure showed that the overall prehypertension occurs among $33.2 \%$ of students $-46 \%$ in males and $30 \%$ in females. The hypertension occurs among $18 \%$ of males and $2.2 \%$ of the females. The differences between the groups are statistically significant $(\mathrm{p}<0.0000)$.

Table 2. Prevalence $(\%, n)$ of participants according to different BMI, WHTR and BP categories

\begin{tabular}{|c|c|c|c|c|c|c|}
\hline \multirow{2}{*}{$\begin{array}{l}\text { Categories } \\
\text { BMI categories }\end{array}$} & \multirow[t]{2}{*}{$\begin{array}{c}\text { All } \\
\%(\mathrm{~N})\end{array}$} & \multicolumn{2}{|c|}{$\begin{array}{l}\text { Males } \\
\%(\mathrm{~N})\end{array}$} & \multirow[t]{2}{*}{$\begin{array}{c}\text { Females } \\
\%(\mathrm{~N})\end{array}$} & \multirow[t]{2}{*}{$\begin{array}{c}\text { Pearson } \\
\text { Chi-square }\end{array}$} & \multirow[t]{2}{*}{ p-value } \\
\hline & & & & & & \\
\hline Underweight & $12.2 \quad(47)$ & 1.2 & (1) & $15.2 \quad(46)$ & & \\
\hline Normal weight & $60.9(235)$ & 55.4 & (46) & $62.4(189)$ & 24.0 & $0.000^{* * *}$ \\
\hline Overweight & $17.9 \quad(69)$ & 32.5 & (27) & $13.9 \quad(42)$ & & \\
\hline Obesity & $9.1 \quad(35)$ & 10.8 & (9) & $8.6 \quad(42)$ & & \\
\hline All & $100.0(386)$ & 100.0 & $(83)$ & $100.0(303)$ & & \\
\hline \multicolumn{7}{|l|}{ WHtR categories } \\
\hline WHtR $<0.5$ & $79.9(307)$ & 68.3 & $(56)$ & $83.1(251)$ & 8.83 & $0.002^{*}$ \\
\hline WHtR $\geq 0.5$ & $20.1 \quad(77)$ & 31.7 & (26) & $16.9 \quad(51)$ & & \\
\hline All & $100.0(384)$ & 100 & (82) & $141 \quad(302)$ & & \\
\hline \multicolumn{7}{|c|}{ Blood pressure categories } \\
\hline Normotension & $61.2(175)$ & 36.1 & (22) & $68.0(153)$ & & \\
\hline Prehypertension & $33.2 \quad(95)$ & 45.9 & (28) & $29.8 \quad(67)$ & 33.2 & $0.000^{* *}$ \\
\hline Hypertension & $5.6 \quad(16)$ & 18.0 & (11) & $(5)$ & & \\
\hline Total & $100.0(286)$ & 100.0 & (61) & $100.0(225)$ & & \\
\hline
\end{tabular}

Note: $\mathrm{WHtR}<0.500$ - without central obesity; WHtR $\geq 0.500$ - with central obesity

Table 3 presents the percentage distribution of the individuals surveyed with different categories of blood pressure according to their body nutritional status, assessed on the basis of BMI. In group ofprehypertensive students from both sexes overall $10.5 \%$ ofparticipants are with underweight, $49.5 \%$ are with normal weigh, $26.3 \%$ are with overweight and $13.7 \%$ are obese. In group of hypertensive overall $43.8 \%$ are with normal weight, $18.7 \%$ are with overweight and $37.5 \%$ are obese. There were statistically significant differences in the percentage distribution of the different blood pressure categories according to their BMI status $(\mathrm{p}=0.000)$. In group of male students with prehypertension the normal weight occurs among 50\%, overweight among $35.7 \%$ and obesity among $10.7 \%$ of males. In group of hypertensivemale students the normal weight occurs among $45.5 \%$, overweight and obesity among $18.2 \% 36.4 \%$, respectively. There are no statistically significant differences in the percentage distribution of different blood pressure categories according to their BMI status in men ( $p>0.326$ ). In group of prehypertensive females with underweight are $13.4 \%$, with normal body nutritional status are $49.3 \%, 22.4 \%$ are overweight and $14.9 \%$ are obese. Hypertension occurs among $40 \%$ of normal weight females, among $20 \%$ of overweight and $40 \%$ of obese female students. There are statistically significant differences in the percentage distribution of different blood pressure categories according to their BMI status $(p=0.007)$. 
Table 3. Prevalence $(\%, n)$ of students with different blood pressure categories according to their nutritional status, evaluated by categories of BMI.

\begin{tabular}{|c|c|c|c|c|c|c|c|c|c|}
\hline \multirow{2}{*}{$\begin{array}{l}\text { Blood pressure } \\
\text { categories } \\
\text { Males }(n=61)\end{array}$} & \multicolumn{2}{|c|}{$\begin{array}{c}\text { Underweight } \\
\%(\mathrm{~N})\end{array}$} & $\begin{array}{c}\text { Normal } \\
\text { weight } \\
\%(\mathrm{~N})\end{array}$ & \multicolumn{2}{|c|}{$\begin{array}{c}\text { Overweight } \\
\%(\mathrm{~N})\end{array}$} & \multicolumn{2}{|c|}{$\begin{array}{l}\text { Obese } \\
\%(\mathrm{~N})\end{array}$} & \multirow[t]{2}{*}{$\begin{array}{l}\text { Chi- } \\
\text { square }\end{array}$} & \multirow[t]{2}{*}{ p-value } \\
\hline & & & & & & & & & \\
\hline Normotension & 0.0 & (0) & $63.4 \quad(14)$ & 27.3 & (6) & 9.1 & (2) & 6.93 & 0.326 \\
\hline Prehypertension & 3.6 & (1) & $50.0 \quad(14)$ & 35.7 & (10) & 10.7 & (3) & & \\
\hline Hypertension & 0.0 & (0) & 45.5 & 18.2 & (1) & 36.4 & (4) & & \\
\hline All & 1.64 & (1) & $54.1 \quad(33)$ & 29.5 & $(18)$ & 14.7 & (9) & & \\
\hline \multicolumn{10}{|l|}{ Females $(n=225)$} \\
\hline Normotension & 14.4 & (22) & $69.3(106)$ & 9.1 & (14) & 7.2 & (11) & 17.59 & $0.007^{*}$ \\
\hline Prehypertension & 13.4 & (9) & $49.3 \quad(33)$ & 22.4 & (15) & 14.9 & (10) & & \\
\hline Hypertension & 0.0 & $(0)$ & 40.0 & 20.0 & (1) & 40.0 & (2) & & \\
\hline All & 13.8 & (31) & $62.8(141)$ & 13.3 & (30) & 10.2 & (23) & & \\
\hline \multicolumn{10}{|l|}{$\operatorname{ALL}(n=286)$} \\
\hline Normotension & 12.6 & (22) & $68.6(120)$ & 11.4 & (20) & 7.4 & (13) & 27.44 & $0.000^{* *}$ \\
\hline Prehypertension & 10.5 & (10) & $49.5 \quad(47)$ & 26.3 & $(25)$ & 13.7 & (13) & & \\
\hline Hypertension & 0.0 & (0) & $43.8 \quad(7)$ & 18.7 & (3) & 37.5 & (6) & & \\
\hline Total & 11.2 & (32) & $60.8(174)$ & 16.8 & $(48)$ & 11.2 & (32) & & \\
\hline
\end{tabular}

Note: Pearson Chi-square - value of Chi-square. p-value - level of significance.

$\mathrm{p}<0.05, \stackrel{\mathrm{k}}{*} \mathrm{p}<0.001-$ significance differences

Table 4 presents the percent distribution of students from different blood pressure categories according to the waist to height ratio (WHTR), giving information about the presence of central (abdominal) obesity.The results showed that in the group of all students with WHTR $<0.500$ overall $67.3 \%$ are normotensive, $28.7 \%$ are prehypertensive and $4 \%$ are hypertensive. In group of central obese students $39 \%$ are normotensive, $49.1 \%$ are prehypertensive and $11.9 \%$ are hypertensive. There were statistically significant differences in

Table 4. Prevalence (\%) of students with different blood pressure categories according to their nutritional status, evaluated by categories of waist to height ratio (WHTR)

\begin{tabular}{|c|c|c|c|c|c|c|c|}
\hline WHTR categories & $\begin{array}{c}\text { Normotension } \\
\%(\mathrm{n})\end{array}$ & Prehy & $\begin{array}{l}\text { pertension } \\
o(\mathrm{n})\end{array}$ & $\begin{array}{r}\text { Hype } \\
0 \\
\end{array}$ & $\begin{array}{l}\text { tension } \\
\text { (n) }\end{array}$ & $\begin{array}{c}\text { Pearson } \\
\text { Chi-square }\end{array}$ & $\mathrm{p}$-value \\
\hline \multicolumn{8}{|l|}{ Males $(n=61)$} \\
\hline WHTR $<0.500$ & $41.5 \quad(17)$ & 41.5 & (17) & 17.1 & (7) & \multirow{3}{*}{1.61} & \multirow{3}{*}{0.446} \\
\hline WHTR $\geq 0.500$ & 25.0 & 55.0 & (11) & 20.0 & (4) & & \\
\hline All & $36.1 \quad(22)$ & 45.9 & $(28)$ & 18.0 & $(11)$ & & \\
\hline \multicolumn{8}{|l|}{ Females $(n=225)$} \\
\hline WHTR $<0.500$ & 73.0 & 25.9 & (48) & 1.1 & (2) & \multirow{3}{*}{14.2} & \multirow{3}{*}{$0.000^{* *}$} \\
\hline WHTR $\geq 0.500$ & $45.0 \quad(18)$ & 47.5 & (19) & 7.5 & (3) & & \\
\hline All & $68.0(153)$ & 29.8 & (67) & 2.2 & (5) & & \\
\hline \multicolumn{8}{|l|}{ ALL $(n=286)$} \\
\hline WHTR $<0.500$ & $67.3(152)$ & 28.7 & $(65)$ & 4.0 & (9) & \multirow{3}{*}{17.16} & \multirow{3}{*}{$0.000^{* *}$} \\
\hline WHTR $\geq 0.500$ & $39.0 \quad(23)$ & 49.1 & (29) & 11.9 & (7) & & \\
\hline Total & $61.2(175)$ & 33.2 & $(95)$ & 5.6 & $(16)$ & & \\
\hline
\end{tabular}

Note: WHTR - waist to height ratio. WHTR $<0.500$ - without central obesity. WHTR $\geq 0.500$ - with central obesity. Pearson Chi-square - value of Chi-square. $\mathrm{p}$ - level of significance. 
the percentage distribution of the different blood pressure categories according to their WHTR status $(\mathrm{p}<0.000)$. In group of male students without central obesity the normotension occurs among 41.5\%, while prehypertension and hypertension among $41.5 \%$ and $17.1 \%$, respectively. In group of central obese male students thenormotenion prevail among $25 \%$, while prehypertension and hypertension among $55 \%$ and $20 \%$, respectively $(\mathrm{p}=0.446)$. In group of females without central obesity the normotension are $73 \%$, prehypertesnion $25.9 \%$ and hypertension $1.1 \%$. Among central obese females $45 \%$ are normotensive, $47.5 \%$ are prehypertensive and $7.5 \%$ are hypertensive $(\mathrm{p}<0.000)$.

Table 5 presents the results of multiple linear regression analysis for study of influence of the anthropometric risk factors on value of blood pressure. As a predictors are waist circumference, body mass index and waist to height ratio and as a dependent variable are systolic and diastolic blood pressure. The results show that waist circumference have a potential to impact significance on the level of systolic and diastolic blood pressure in young females and on diastolic blood pressure in young males $(\mathrm{p}<0.05)$. The other anthropometric indicators such as BMI and WHTR have a insignificant impact on the values of blood pressure-systolic and diastolic in this early period of life.

Table 5. Multiple regression analysis of obesity measures with blood pressure

\begin{tabular}{llcccccc}
\hline $\begin{array}{l}\text { Dependent } \\
\text { variable }\end{array}$ & Predictors & Beta(b*) & St. Err of $b^{*}$ & p-level & Beta(b*) & St. Err of b* & p-level \\
\hline SBP & WC & Female & Male & & & & \\
\cline { 2 - 7 } & BMI & 0.619 & 0.233 & $0.008^{*}$ & 0.779 & 0.490 & 0.117 \\
& WHTR & -0.302 & 0.122 & 0.651 & 0.227 & 0.342 & 0.509 \\
& Female & Male & 0.186 & -0.680 & 0.516 & 0.192 \\
\hline DBP & WC & 0.373 & 0.242 & $0.000^{*}$ & 1.620 & 0.462 & $0.000^{*}$ \\
& BMI & 0.156 & 0.126 & 0.125 & 0.177 & 0.323 & 0.585 \\
& WHTR & -0.242 & 0.236 & 0.216 & -1.532 & 0.486 & $0.002^{*}$ \\
\hline
\end{tabular}

Note: WC - waist circumference cm. BMI - body mass index, $\mathrm{kg} / \mathrm{m}^{2}$. WHTR - waist to height ratio. $\mathrm{SBP}$ - systolic blood pressure, $\mathrm{mmHg}$. DBP - diastolic blood pressure, $\mathrm{mmHg}$. Beta - regression coefficient. $\mathrm{p}$ - level of significance of regression coefficient.

\section{Discussion}

This study presents original new data for prevalence of the prehypertension, hypertension and other cardiovascular and metabolic risk factors among Bulgarian university students.

According to our results the prevalence of underweight in male (4.5\%) is lower compared to the data of National Rerpesentative Survey from Nutrition and Nutritional status of the Bulgarian population, conducted in 2004 by Petrova et al. (2012), for the group 19-29 years, as well as of the data of other Bulgarian's (Birdanova et al., 2013) and foreign authors (Daud, Javaid, 2012). At the same time the prevalence of underweight among our female students is $15.2 \%$. It is lower than established results by other Bulgarian authors $-17.3 \%$, according to Petrova et al. (2012) and 18\% according to data of Birdanova et al. (2013).Also, the underweight in our students is significantly lower than the results published in 2010-2011 for students from other countries - 26.8\% for Denmark (Skovlund et al., 2011) and 25.7\% for Turkey (Unal et al., 2010).

Our study showed that the total prevalence of overweight and obesity among students from both sexes are $17.9 \%$ and $9.1 \%$ respectively. The prevalence of overweight is $32.5 \%$ 
for men and $13.9 \%$ for women. According to the results obtained at today's Bulgarian male students there is a higher frequency of overweight encounter, according to Petrova et al. (2012) from a data of National Representative Survey for Bulgaria (NRS), where the overweight in males from $19-29$ years is $23.3 \%$. The rate of obesity in male students in our study $(10.8 \%)$ is also higher than the percentage rate of obesity in NRS $(6 \%)$ conducted in 2004. At the same time, the $13.9 \%$ prevalence rate of overweight among our female students is lower than previous established results, reported in NRS $-18.1 \%$. Our results are very similar to results of other Bulgarian authors (Birdanova et al., 2013) for female medical students from Pleven town, where the overweightis $10.9 \%$. Overall obesity prevail among $8.6 \%$ of the female students in current study, which is twice more, compared to results of other Bulgarian authors (Petrova et al., 2012; Birdanova et al., 2013).

In the group of the young women the"double burden" is observed - on the one hand, an increased prevalence of overweight and obesity and on the other hand an increased prevalence of underweight. There is a potential risk for the physical and reproductive health of this women, connected with their nutritional status and underweight. This our results corresponded with results of other authors that found similar tendency among young women and girls in Bulgaria (Petrova et al., 2012; Birdanova et al., 2013) and other countries on the world (Lee, Ryu, 2018; Khan and Khoi, 2008).

Data from a study conducted in Copenhagen in 2011 among medical students (Skovlund et al., 2011) show average rates of overweight of $7.3 \%$ for female and $9.7 \%$ for male students, which is significantly lower than the rate found in our survey. The relative share of overweight (2.8\%) and obesity (4.7\%) among Turkish university students (Unal et al., 2010) are lower compared with our data. The similar share of overweight $-21 \%$ and very lowest percent of obesity, compared with our data were found among Serbian university students of Crnobrnja et al. (2012). The authors also were found the higher frequency of overweight and obesity in male respondents.

For a considerable spread an overweight and obesity over the past two decades among university students from a many European Universities in Italy, Spain, Czech Republic, Greece reported many authors (Emmons, 2000; Karen et al., 2009; Michael et al., 2011). The relative share of overall overweight and obesity among students in Europe ranges between 20.5-30\%, where a values among female are approximately two times lower.

Many authors reported that the waist- to- height ratio (WHTR) showed the highest correlation with intraabdominal fat compared to BMI, waist circumference and waist-to-hip ratio (Aswell et al.,1985; Hsiesh and Muto, 2005). WHTR was first used in the Framingham study (Higgins et al., 1988) and proved to be weakly associated with age. We used this index to evaluation of central (abdominal) obesity among Bulgarian students. Acording to WHTR cut-off points our results show that prevalence of central obesity among students is $20.1 \%$, independently of sex. Male students suffered central obesity at a higher rate $-31.7 \%$, compared to female students- $16.9 \%$. Our results are show significant lower prevalence of central obesity compared with Egypt students-43.9\% (Farrag et al., 2015) and other.

The present study found that the total prevalence of prehypertension independently of sex is $33.2 \%$, while the hypertension prevail among 5.6\% of respondents, respectively. Results of our study were similar to results of recent study in Turkey (Aynaci, Akdemir, 2018), where rate of hypertension was the same $-5.6 \%$. but the rate of prehypertension is very lower $(8.6 \%)$, than our data. The results for current study for prehypertension and hypertension were lower compared to the results of other study in students from India (Jain et al., 2014), Malaysia (Cheah et al., 2018). Also our results showed insignificant lower percentage on hypertension compared with studies that found 7\% hypertension in Kuwait (Al-Majed, Sadek, 2012) and 7.5\% in Saudi Arabia (Baig et al, 2015). 
Gender also contributed to the significant association towards hypertension. Therewas a greater proportion of males who were hypertensive compared to females. This was consistent with other studies (Gharaibeh et al 2012; Cheah et al., 2018 Sakurai et al., 2006). This differences, according to may be due to data collection methods, the socioeconomic status of the evaluated population, and differences in healthy lifestyle behaviours (Aynaci, Akdemir, 2018). Also, the higher prevalence of elevated blood pressure among men could be explained by the fact that hormones, suchas testosterone, can play an important role in gender-associated differences in blood pressure regulation, as well as have a protective effect, such as oestrogen in females. It was further explained by Celermajer et al. (1994) that gender differences can affect the arterial physiology of a human being. Men tend to exhibit a gradual decline in endothelial responses after the age of 40, but a woman's vascular physiology remains normal for another 10 years beyond 40 . However, once a woman reaches menopause, the rate of decline in endothelial responses willincrease. Hence, women's risk of hypertension will eventually be the same as men's.

Our results are confirmatory the fact for higher percent of hypertensive male and show that the risk-based cardiovascular and metabolic factors studied are more common among males, than females. Sex "male" is associated with a higher risk of cardiovascular and metabolic diseases from a young age among Bulgarian people. This fact is to connect with higher relative share on cases with prehypertension and hypertension, and also prehypertension and hypertension combined with overall and central obesity among men, compared with women.

According to sex, the our results show that $18 \%$ of male and $2.2 \%$ of female were hypertensive, and another $45.9 \%$ of male and $2.8 \%$ of female are prehypertensive. The higher prevalence of elevated blood pressure among Bulgarian male students maybe connect with factors such as a sex, hormonal status, hereditary burden and sexual differences in some lifestyle habits as a nutrition, smoking, alcohol consumption, physical activity, individual physiological and biochemical status, higher sensitivity on stress, and other. The current our results corresponded with other studies that reported for higher prevalence of hypertension in males (Celermajer et al., 1994; Sakurai et al., 2006; Gharaibeh et al 2012; Cheah et al., 2018).

The prevalence of prehypertension and hypertension among young Bulgarian adults needs of urgent attention and further evaluation because of the grave consequences of hypertension and because secondary hypertension is likely in this age group. Lee and Cooper (2009) suggested that for CVD the hypertension is an important amendable risk factor.

The current study demonstrate a significant association of systolic blood pressure with waist circumference among male $(\mathrm{p}<0.008)$, and between waist circumference and diastolic blood pressure among students from both sexes $(\mathrm{p}<0.000)$. The other anthropometric factors such as a BMI and WHTR have an impact on the level of blood pressure also, but lower and insignificant. Therefore, this overall finding agrees with other studies (Amandeep et al., 2009; Dalton et al. 2003 and other) and suggests significant prevalence of risk factors in Bulgarian university students. Therefore, it may be suggested from the present study that proper population based monitoring and modified lifestyle for cardiovascular risk will decline the cardiovascular mortality in young Bulgarian population.

Our results also show that at this young age (18-30 years) the waist circumference has a serious potential to affect the blood pressure level at an early adulthood in both sexes. Similar results was found of other authors (Jain et al., 2014). In the aforementioned study, the pressure components - SBP and DBP correlated to all of the evaluated anthropometric indicators, but WC has shown higher correlation both in males and females. (Jain et al., 2014).Our results confirm this fact.

Although BMI is the most studied index, being significantly related to CVD risk factors as demonstrated by cross-sectional and prospective studies (Yusuf et al., 2004), there are increasing 
doubt about its role in predicting CVD events which has led to an increasing focus for abdominal obesity indices (Ribeiro et al. 2010; Mladenova and Andreenko, 2015; Andreenko et al., 2015a, 2015b)

The increase of prevalence of overweight, general and central obesity and prehypertension and hypertension among Bulgarian university students could be explained by the heredity burden, psychological stress during student life, lack of time and financial resources for quality and healthly food, by the tobacco use, alcohol consumption and sedentary lifestyle.

\section{Conclusion}

The percent of Bulgarian university students with overall and abdominal obesity, prehypertension and hypertension increases.This tendencies more often pronounced among male students. In the group of the female students the "double burden" is observed - on the one hand, an increased prevalence of overweight and obesity and on the other hand an increased prevalence of underweight. The relative share of young people with combination of overweight and obesity and with central fat accumulation and elevated blood pressure increases in both sexes and occurs more often among men. The waist circumference has a serious potential to affect the blood pressure level at an early adulthood in both sexes. The higher prevalence of elevated blood pressure, overweight and central and abdominal obesity among Bulgarian students maybe connect with factors such as a sex, hormonal status, hereditary burden and sexual differences in some lifestyle habits as a nutrition, smoking, alcohol consumption, physical activity, individual physiological and biochemical status, psychological stress during student life and other. The prevalence of prehypertension and hypertension among young Bulgarian adults needs urgentattention and further evaluation because of thegrave consequences of hypertension and becausethe hypertension is an important amendable riskfactor.

\section{Limitations}

The major limitations of this survey is the relatively small number of participants. Because the sample was taken only university students, this could not be representative to the whole sector of young adults in Bulgaria. Inclusion of family history of CVD risk factors could enhance the interpretation of risk factors in our participants. However, this was beyond our scope.

Acknowledgements. This study was realized with financial support of the Scientific Researches Fund at Plovdiv University "Paisii Hilendarski", under project: "Heterotopy of the health on population in reproductive age", contract number SR15- FS-017 and project "Memoria de futuro- multidisciplinary aspects of human studies", contract number FP17- FS-011.

\section{References}

Al-Majed, HT, Sadek, AA. (2012). Pre-hypertension and hypertension in college students in Kuwait: a neglected issue. J Family Community Med, 19 (2):105-12. https://doi.org/10.4103/2230-8229.98296 PMid:22870414 PMCid:PMC3410173.

Amandeep, B., Kaur Brar, S., Kumar, R. (2009). Age specific relation of blood pressure with anthropometric variables among 19-24 years Punjabi female youth of Amritsar city in Punjab, India. The Anthropologist, 11(3):207-211. 
Andreenko, E. (2005). Variations in the Body Mass Index (BMI) of Middle-Aged Men: Effects of the Occupation, Age and Social Class. Acta morphologica et anthropologica, 10, 203-206.

Andreenko, E. (2009). Changes in the body composition and obesity in men aged 20-50 years. Journal of Biomedical and Clinical Research, 2 (suppl. 1): 117-120.

Andeeenko, E., Nikolova, M (2010). Topical distribution of the subcutaneous fat tissue on some parts and regions of the body in children and adolescents from South Bulgaria. Biotechnology \& Biotechnological Equipment. 24/2010/SE, 342-346.

Andreenko, E., Mladenova, S., Akabaliev, V. (2015a). Anthropometric obesity indices in relation to age, educational level, occupation and physical activity in Bulgarian men. Nutricion Hospitalaria, 31(2):651-658.

Andreenko, E., Mladenova, S., Akabaliev, V. (2015b). Influence of Socio-economic, Dietary and Behavioral Factors on Overweight and Obesity in Bulgarian Men. The Anthropologist, 21(1-2):71-79.

Andreenko, E., Mladenova, S., Tineshev, S., Naydenov, M., Petrova, N. (2017). Anthropometric indices for obesity and potential health risk of Plovdiv students. Scientific Researches of National Scientific Conference "Education and Science-for Personal and Social Development" Smolyan 2017, Bulgaria, Vol. 2 , part "Biology and Chemistry. Medicine", 195-205 (In Bulgarian).

Ashwell, M., Cole, T., Dixon, A.(1985). Obesity: new insight into the anthropometric classification of fat distribution shown by computed tomography. BMJ, 290: 1962-1964.

Aynaci, G., Akdemir, O. (2018). The Relationship Between Lifestyle, Health Promotion Lifestyle Profile II and High Blood Pressure In University Students. Open Access Maced J Med Sci, 6(9):1756-1761. https://doi.org/10.3889/oamjms.2018.314

Baig, M., Gazzaz, Z., Gari, M., Al-Attallah, H., Al-Jedaani, K., Mesawa, A. et al.(2015) Prevalence of obesity and hypertension amongUniversity students' and their knowledge and attitude towards risk factors of Cardiovascular Disease (CVD) in Jeddah, Saudi Arabia.Pak J Med Sci ,31(4):816-820. doi: http://dx.doi.org/10.12669/pjms.314.7953

Birdanova, V., Penkov, A., Stoynovska, M., Petkov, K., Statev, N.(2013). Investigation Of Nutritonal Status Among Medical University Students By Antropometric Indices. Science Dietetics, 1-2, 27-32 (Article in Bulgarian).

Brandao, M., Pimentel, F., Silva, C., Cardoso, M. (2008). Risk factors for cardiovascular disease in a Portuguese university population. Rev Port Cardiol, 27(1):7-25.

Celermajer, D., Sorensen, K., Spiegelhalter, D., et al.(1994). Aging is associated with endothelial dysfunction in healthy men years before the age-related decline in women. J Am Coll Cardiol, 24:471-476.

Cheah, W., Helmy, H., Chia, H., et al.(2018). Hypertension and its association with anthropometric indexes among pre-university students. Int J Adolesc Med Health. Malays Fam Physician, 13 (1): 2-9.

Chobanian, A., Bakris, G., Black, H., Cushman, W., Green, L., et al. (2003). The seventh report of the Joint National Committee on detection, evaluation and treatment of high blood pressure: the JNC 7 report. JAMA, 3;289:2560-72.

Crnobrnja, V., Srdić, B., Stokić, E., Dujmović, F., Andrejić, B.(2012).Analysis of obesity prevalence in students from Novi Sad.Med Pregl. 65(3-4):133-7. (Article in Serbian).

Dalton, M., Cameron, A., Zimmet, P., Shaw, J., Jolley, D., Dunstan, D., Welbom, T.(2003). Waist circumference, waist hip ratio and body mass index and their correlation with cardiovascular disease risk factors in Australian adults. J Intem Med, 254: 555- 563.

Daud, S., Javaid, F. (2012). Estimation of Body Mass Index (BMI) in medical students. $-P J M H S, 1,5$ : 702-705.

Dyakova,M., Shipkovenska, E., Dyakov, P., Dimitrov, P., Torbova, S.(2008) Cardiovascular Risk Assessment of Bulgarian Urban Population: Crosssectional Study.Croat Med J, 49:783-91.

Emmons, K. (2000). Behavioral and social sciences contributions to the health ofadults in the United States. - In: Smedley, B., S. Syme (Eds.). Promotinghealth: intervention strategies from social and behavioral research.(pp.254-321).Washington,DC, Institute of Medicine, National Academy Press.

Farrag, A., Eraky, A., Aroussy, W., Sayed, G., Mahrous, A. et al. (2015). Obesity and Other Cardiovascular Risk Factors in Egyptian University Students: Magniude of the Problem. Epidemiology (sunnyvale) 5: 181, doi:10.4172/2161-1165.1000181. 
Feliciano-Alfonso, J.,Mendivil, C., Ariza, I., Perez, C. (2010). Cardiovascular risk factors and metabolic syndrome in a population of young students from the National University of Colombia. Rev Assoc Med Bras. 56(3):293-298.

Furukawa, Y.,Ehara, N.,Taniguchi, R., Haruna, Y., Ozasa, N., Saito, N., Doi, T. et al.(2009). Coronary risk factor profile and prognostic factors for young Japanese patients undergoing coronary revascularization. Circ J,73(8):1459-1465.

Gharaibeh, M., Alzoubib, K., Khaboura, O., Tinawia, L., Hamada, R., Keewanc, E., Matarnehb, S., Alomarid, M.(2012). Assessment of Cardiovascular Risk Factors Among University Students: The Gender Factor. Cardiol Res, 3(4):172-179.

Higgins, M., Kannel, W., Garrison, R., Pinsky, J., Stokes, J. (1988). Hazards of obesity-the Framingham expeience. Acta Med Scand Suppl, 723: 23-36.

Hsieh, S., Muto, T. (2005). The superiority of waist-to-height ratio as an anthropometric index to evaluate clustering of coronary risk factors among non-obese men and women. Prev Med, 40: 216-20.

Jain, J., Mathur, H., Apte, S., Sinha, U., Agarwal, K., Chanchlani, R.(2014).Prevalence of Prehypertension and Hypertension and its Correlation with Anthropometric Measurements in Medical Students of Central India. Journal of Evolution of Medical and Dental Sciences, 3 (10): 2429-2433.doi: 10.14260/jemds/2014/2155.

Karen, K., Amy, S., Flora, H., et al.(2009). The contributions of weight problem perception, BMI, gender, mood, and smoking status to binge eating amongcollege students. Eating Fehaviors, 10: 1-9.

Khan, N., Khoi, H. (2008). Double burden of malnutrition: the Vietnamese perspective. Asia Pac J Clin Nutr, 17 (1): 116-8.

Lee, S., Ryu, H. (2018). Relationship between dietary intakes and the double burden of malnutrition in adults of Malang, Indonesia: An exploratory study. Nutr Res Pract,12(5):426-435. doi: 10.4162/nrp.2018.12.5.426. Epub 2018 Oct 1.

Lee, D., Cooper, R. (2009). Recommendations for global hypertension monitoring and prevention. Curr Hypertens Rep, 11:444-9.

Li, S., Chen, W., Srinivasan, S. (2003). Childhood cardiovascular risk factors and carotid vascular changes in adulthood: the Bogalusa Heart Study. JAMA,290: 2271-6.

Mackay, J., Mensah, G. (2004). World Health Organization. The Atlas of Heart Disease and Stroke. Geneva, WHO.

Martin, R., Saller, K. (1957). Lehrbuch der Anthropologie.Stuttgart: Gustav Fisher Verlag, 1- 661.

Michael, C., Thrasivoulos, T., Chryssa, P., et al.(2011). Evaluation of dietary habits and assessment of cardiovascular disease risk factors among Greek universitystudents. - Appetite, 57: 377-383.

Mitova, Z.(2010). Relation between the nutritional status type and the arterial blood pressure in 9-15 -yearold schoolchildren from Sofia. Acta morphologicaet anthropologica, 16: 76-87.

Mladenova, S., Andreenko, E. (2015). The prevalence of high-normal blood pressure and hypertension among 8 to 15 -year old Bulgarian children and adolescents with various nutritional status (Smolyan region, 2012-2014). The Anthropologist, 21 (1,2):51:60.

Nikolova, M. (1994). Genetic and Environmental influences on morphological characteristics. The Mankind Quarterly, vol.XXXV,1994, 1-2, 27-38.

Nikolova, M., Sivkov, S., Akabaliev, V., Mladenova S. (2005). Body composition of children and adolescents in Plovdiv. Proceedings from Balkan Scientific Conference of Biology, Plovdiv University Press, p. 150-159.

Paavola, M., Vartianinen, E., Haukala, A. (2004). Smoking, alcohol use, and physical activity: a 13-year longitudinal study ranging from adolescence into adulthood. JAdolesc Health, 35: 238-44.

Petrova, S., Duleva, V., Rangelova, L.(2012). Monitoring on nutritional status of Bulgarian population: prevalence and trends of obesity and underweight. Science Dietetics, 2: 18-29 (Article in Bulgarian).

Physical status: the use and interpretation of anthropometry (1995). Report of a WHO Expert Committee. World Health Organ Tech Rep Ser, 854:1-452.

Ribeiro, R., Coutinho, M., Bramorski, M. (2010). Association of the Waist-to- height ratio with cardiovascular risk factors in children and adolescents: The three cities heart study. Int J Prev Med, 1(1): 39-49.

Rogacheva, A., Laatikainen, T., Tossavainen, K., Vlasoff, T., Panteleev, V., Vartiainen, E.(2006). Changes in cardiovascular risk factors among adolescents from 1995 to 2004 in the republic of Karelia, Russia. Eur J Pub Health, 17(3): 257-62. 
Sakurai, M., Miura, K., Takamura, T., Ota, T., Ishizaki, M., Morikawa, Y., Kido, T., Naruse, Y., Nakagawa, H. (2006). Gender differences in the association between anthropometric indices of obesity and blood pressure in Japanese. Hypertens Res., 29 (2):75-80.

Skovlund, A., Hasle, N., Toftegaard Pedersen, L., Peterson, B.(2011). Female medical students are estimatedto have a higher risk for developing eating disorders than male medicalstudents. Dan Med Bul, 58: 1-5.

Stojanovic, D., Visnjic, A., Mitrovic, V., Stojanovic, M. (2009). Risk factors for the occurrence of cardiovascular system diseases in students. Vojnosanit Pregl.

66(6):453-8.

Unal, A., Nazan, E., Osman, S. (2010).Eating habits, lifestyle factors, and bodyweight status among Turkish private educational institution students. Nutrition,2010, 26: 772-8.

World Health Organization. Noncommunicable Diseases(NCD) Country Profile, 2015.

World Medical Association Declaration of Helsinki.(2000). Ethical principles for medical research involvinghuman subjects. JAMA, 284(23): 3043-45.

Yusuf, S., Ounpuu, S., Dans, T. (2004). Effect of potentially modifiable risk factors associated with myocardial infarction in 52 countries (the INTERHEART study): case-control study. Lancet, 364: 937-52.

\title{
PREVALENCIJA ANTROPOMETRIJSKIH I KARDIOVASKULARNIH FAKTORA RIZIKA KOD BUGARSKIH STUDENATA UNIVERZITETA
}

\author{
Silviya Mladenova
}

Sažetak. Ovaj rad istražuje prevalenciju kardiovaskularnih faktora rizika i njihovu povezanost sa antropometrijskim faktorima kod studenata univerziteta u Bugarskoj, uglavnom u južnoj Bugarskoj.Ispitivani uzorak obuhvatio je 386 mladih ljudi, 303 žena i 83 muškarca, starosti između 18 i 30 godina i prosečne starosti 21,2-21,3 godine. Studenti su bili iz različitih regiona Bugarske, ali uglavnom iz južne Bugarske. Sprovedeno je transverzalno ispitivanje u periodu od 2015. do 2017. godine. Svakom ispitaniku utvrđivani su telesna težina, telesna visina, obim struka i krvni pritisak. Prema formulama su na osnovu ovih vrednosti određivani indeks telesne mase (body mass index - BMI) i odnos obima struka i telesne visine (Waistto-height ratio - WHtR). Pothranjenost je definisana $\mathrm{kao} B M \mathrm{Bl}<18.5 \mathrm{~kg} / \mathrm{m}^{2}$, povišena telesna masa je za BMI $u$ intervalu $25-29.9 \mathrm{~kg} / \mathrm{m}^{2}$, a gojaznost je definisana za BMI $\geq 30 \mathrm{~kg} / \mathrm{m}^{2}$. Odnos obima struka i telesne visine (WHtR) je korišćen za procenu centralne (abdominalne) gojaznosti i ona je definisana kao $\mathrm{WHtR} \geq 0.5$. Prehipertenzija se definiše za SBP $>120$ $<139$ i/ili DBP > $80<89 \mathrm{mmHg}$, a hipertenzija ukoliko je SBP $\geq 140$ i/ili DBP $\geq 90 \mathrm{mmHg}$. Statistička obrada podataka obavljena je korišćenjem softvera Statistica 10.0 i SPSS 20.0, metodama descriptivne statistike i multiplom regresionom analizom. Rezultati pokazuju da je pothranjenost prisutna kod $1,2 \%$ pripadnika muškog i $15,2 \%$ ženskog pola, povećana uhranjenost prisutna je kod 32,5\% ispitanika muškog i 13,9\% ispitanika ženskog pola, a gojazno je $10,8 \%$ ispitanika muškog i $8,6 \%$ ispitanika ženskog pola. Sa centralnom gojaznošću je $32 \%$ ispitanika muškog i $17 \%$ ispitanika ženskog pola, nezavisno od statusa njihove ishrane. Prehipertenzija se javlja kod $46 \%$ muškaraca i $28 \%$ žena. Hipertenziju nalazimo u $18 \%$ muškaraca i $2 \%$ žena. Kod muških studenata sa prehipertenzijom, povišenu telesnu masu ima 35,7\%, a gojazno je oko 10,7\%, dok je kod muških studenata sa hipertenzijom, povišena telesna masa prisutna je kod $18.2 \%$, a gojaznost kod $36,4 \%$. U grupi prehipertenzivnih studentkinja $22,4 \%$ je sa povišenom telesnom masom, a 14,9\% je gojazno. Hipertenzija je prisutna kod $20 \%$ njih sa povećanom uhranjenošću i kod $40 \%$ gojaznih studentkinja. U grupi muških studenata sa centralnom gojaznošću prehipertenzija je prisutna kod 55\%, a hipertenzija kod $20 \%$. U grupi studentkinja sa centralnom gojaznošću 47,5\% je sa prehipertenzijom, a 7,5\% sa hipertenzijom. Rezultati su takođe pokazali da je obim struka značajno može da utiče na nivo krvnog pritiska kod mladih odraslih osoba oba pola. Viša prevalenca povišenog krvnog pritiska, povišena telesna masa, opšta i centralna gojaznost 
kod studenata univerziteta u Bugarskoj može biti povezana sa faktorima kao što su pol, hormonski status, genetska predispozicija i polne razlike u nekim životnim navikama kao što su ishrana, pušenje, konzumiranje alkohola, fizička aktivnost, individualni fiziološki i biohemijski status, psihološki stres za vreme studentskoh života i drugo. Prevalenca ovih faktora rizika kod studenata univerziteta u Bugarskoj zahteva hitnu reakciju i dalju evaluaciju zbog teških posledica gojaznosti i hipertenzije i zbog toga što su hipertenzija i povišena telesna masa važni faktor rizika koji se mogu menjati tokom mladosti.

Ključne reči: prehipertenzija, hipertenzija, povišena telesn masa, gojaznost. centralna gojaznost, studenti bugarskih univerziteta. 